\title{
Beyond the Enclave: Success Strategies of Immigrant Entrepreneurs
}

\author{
José Delfín González \\ Belmont University \\ Douglas G. Campbell \\ Walden University
}

In the United States, immigrant entrepreneurs start almost one third of all new businesses. However, many immigrant entrepreneurs lack the knowledge or expertise to evolve their businesses beyond the ethnic enclave where their businesses are located. This multiple case study captured the strategies used by five Latino immigrant business owners who successfully expanded their business beyond their ethnic enclave. The conceptual framework for this study was dynamic capabilities theory. Data were collected from interviews, company documents, and observations of the operation of businesses and owners. Member checking and transcript reviews were used to enhance the reliability and credibility of the data. Miles, Huberman, and Saldana's data analysis method was used to identify six themes that yielded three possible strategies to help Latino immigrant business owners expand outside of their enclave: (a) adopt a multicultural hybridism model changing the internal makeup of the employee base to include more interethnic labor and managerial resources; (b) achieve language and cultural proficiency of the host community; and (c) seek and nurture professional development and mentorship relationships to obtain access to advice, opportunities, and financial resources. Also noted was the importance of individual readiness to seize opportunities and being tenacious in their business efforts. The study findings may contribute to positive social change because strategies that help immigrant entrepreneurs succeed have benefits that extend beyond their immediate family to the broader communities in which they operate by increasing job creation, wealth accumulation, and the development of society.

Keywords: immigrant, entrepreneurs, Latino, enclave, Nashville

\section{Introduction}

Immigrants who come to the United States bring hope, energy, and, in many cases, an entrepreneurial desire to partake in the dream of owning their own business (Agius \& Canizales, 2016; Kwon, Heflin, \& Ruef, 2013). However, immigrant entrepreneurs often face obstacles as they grow their businesses (Ndofor \& Priem, 2011). Many of these immigrants, especially the poorest ones from Latin American nations, have limited formal education and limited English language skills (Pandya, Batalova, \& McHugh, 2011; Salcido \& Menjívar, 2012). Sometimes, they start microbusinesses within the ethnic enclave where they live and achieve enough success to support themselves and their family's modest lifestyles (Kallick, 2015). Relatively few immigrant Latino small business owners in the United States have successfully expanded their businesses outside of their immigrant enclave to achieve financial independence (Ndofor \& Priem, 2011; Riva \& Lucchini, 2015; Xie \& Gough, 2011). The purpose of this qualitative multiple case study was to explore the strategies used by five Latino immigrant small business owners residing in Nashville, Tennessee, to expand their businesses beyond their ethnic enclave where their businesses were initially located. 


\section{Research Method, Design, and Conceptual Framework}

The research question was as follows:

Research Question: What strategies do Latino immigrant business owners in Nashville, Tennessee, use to expand their businesses outside of the ethnic enclaves where their businesses are located?

The multiple case exploratory study design was chosen for this study. By using this design, we interviewed and collected data from five Latino business owners who have experienced success venturing out of their ethnic enclave; this enriched the understanding of the issue under investigation. Capturing insights directly from Latino business owners allowed us to develop a holistic, complex, and complete picture to identify the strategies they used to expand such business beyond an ethnic enclave. Data was collected by interviewing the businesses owners, reviewing documents, and observing the characteristics and operations of the businesses. Member checking and transcript reviews were used to enhance the reliability and credibility of the data collected from interviews.

The theory of dynamic capabilities served as the conceptual framework and lens through which the data was analyzed. Teece, Pisano, and Shuen (1997) were the first ones to offer dynamic capabilities as an abstract framework to study competitive advantage in enterprising firms. Dynamic capabilities, in this context, are the distinct skills, processes, organizational structures, decisions, and rules that determine a firm's ability to reconfigure its internal and external competencies to respond to external business environments (Teece, 2012).

\section{Synthesis of the Literature Review}

Research into ethnicity and entrepreneurship has its roots with works of Weber (1930), Sombart (1914), and Simmel (1950). In general, immigrant entrepreneurship researchers support the notion that immigrant entrepreneurship lays at a particularly important juncture between economics and sociology (Ibrahim \& Galt, 2011; Ilhan-Nas, Sahin, \& Cilingir, 2011). Although economists and business scholars have dominated the study of entrepreneurship, scholars in fields as diverse as sociology, demography and urban planning have studied immigrant entrepreneurship (Jennings, Greenwood, Lounsbury, \& Suddaby, 2013). Because management is a multidisciplinary field of research that draws from finance, business, psychology, philosophy, sociology, and several other disciplines to examine phenomenon, this study was undertaken through an interdisciplinary lens.

Immigrants have been highly industrious in finding alternative ways of earning a livelihood, including informal self-employment (Ortiz-Walters, Gavino, \& Williams, 2015). Carter (2011) noted that business ownership is frequently a vital alternative to wage and salary employment for making a living and thus has important implications for earnings and wealth inequality. Much of the research on why immigrants pursue entrepreneurial endeavors has mostly focused on the factors that incentivize or hinder immigrant startups (Chand \& Ghorbani, 2011; Curci \& Mackoy, 2010). For example, research undertaken when exploring immigrant entrepreneurship includes the loss of human capital gained when moving abroad, such as foreign-earned credentials (Creese \& Wiebe, 2012) and individual network contacts (Buzdugan \& Halli, 2009) or English proficiency issues that become a hindrance to business venture formation and integration (Wang, 2011).

Immigrant entrepreneurship is a topic that has been widely studied by scholars around the world (Braymen \& Neymotin, 2014; Chrysostome \& Lin, 2010; Curci \& Mackoy, 2010; Ndofor \& Priem, 
2011; Pisani, 2012; Zolin \& Schlosser, 2012). There has been much research on the role of immigrant entrepreneurship in host-country economies. This research has yielded a large body of literature on the start-up and development of immigrant-owned businesses (Huerta, 2011; Kim, 2012; Ndofor \& Priem, 2011). The topic is more common in countries that have experienced visible growth in immigrant communities because of global migration patterns, particularly those societies where business entrepreneurship is a means to benefit the economic stance of low-income immigrants (Raijman \& Kemp, 2009).

Much of the literature on immigrant entrepreneurship focuses on the choice of self-employment as an alternative to a poorly paid labor market (Ilhan-Nas et al., 2011). However, a new vein of research has received attention from researchers who are focusing on studying the engagement of immigrant businesses catering to mainstream segments of the economy and who increasingly serve markets with nonethnic products and services (Arrighetti, Bolzani, \& Lasagni, 2014).

Many immigrant-owned businesses are launched within ethnic enclaves (Ndofor \& Priem, 2011). Ethnic enclaves offer a safer and more easily accessible space for immigrant businesses to operate when they launch their ventures. Enclaves provide an environment shielded from competition of nonethic businesses, yet they also offer limited profit and growth potential (Arrighetti et al., 2014). The enclave creates opportunities but also marks the boundaries of an economic space that ethnic firms cannot easily overcome. The nature of their product or service offering, the lack of articulation of their business model, and their limited managerial experience generally make the ethnic firms noncompetitive in mainstream markets, despite the fact that venturing in mainstream markets may provide a platform for achieving better financial returns and a better quality of life (Ma, Zhao, Wang, \& Lee, 2013).

The immigrant entrepreneur paradigm has emerged in an attempt to understand how immigrants access business ownership (Chrysostome \& Lin, 2010; Lofstrom, 2011). Curci and Mackoy (2010) recommended researchers should consider personal, economic, and institutional factors to understand the immigrant business entrepreneurship phenomenon. Ndofor and Priem (2011), for example, conducted a study of 103 immigrant-owned business ventures in the Midwest and concluded that a range of capital endowments and social identities influenced their choice of venture strategies as well as their outcomes.

Three major perspectives have emerged from the literature that explain why and how immigrants pursue entrepreneurial activities. These are blocked mobility, cultural predisposition, and ethnic enclaves (Fitzgerald \& Howe-Walsh, 2009; Kirkwood, 2009; Lofstrom, 2011). These approaches detail various conceptual frameworks that explain why and how immigrants pursue entrepreneurship, primarily focusing on the dynamics that incentivize or hinder business endeavors undertaken by immigrants. These views recognize that different immigrant groups have very distinct entrepreneurial journeys based on social class, geography, education level, or other stratifying differences (Krittayapong, 2012).

Even though these three perspectives have emerged, few researchers have focused on the exploration of how immigrant entrepreneurs who begin their ventures by focusing on selling in ethnic enclaves, then evolve and adapt their strategies to expand their customer base beyond the enclave and to a broader market.

The limited amount of contemporary scholarship in the area of immigrant entrepreneurship research seems to suggest that immigrant entrepreneurs who eventually abandon their ethnic enclave or ethnocentric strategy are favored by earning better returns on their ventures as they target mainstream customers (Braymen \& Neymotin, 2014; Ensign \& Robinson, 2011; Trevizo \& Lopez, 
2016). In 2014, Braymen and Neymotin, using Kauffman Foundation data from 2004 to 2008, found a statistically significant negative effect on firm profitability for businesses that were located in immigrant enclaves. Ndofor and Priem (2011) used field study data to conclude that immigrant entrepreneurs who have high levels of economic capital and weak social ties to an ethnic enclave are better prepared to succeed outside an ethnic enclave. Trevizo and Lopez (2016) also found that immigrant firms located in immigrant enclaves tend to experience more difficulty achieving higher levels of success as measured by a lower number of paid employees they hire. In a study conducted with Mexican immigrant-owned storefronts in Los Angeles, California, Trevizo and Lopez concluded that performance of these ventures was hindered precisely by the spatial segregation created by operating in enclaves.

\section{Findings}

Miles, Huberman, and Saldana's (2014) data analysis method was used to identify six themes that yielded three possible strategies to help Latino immigrant business owners expand outside of their enclave.

\section{Theme 1: Opportunity Readiness}

As discussed by the participants, opportunity readiness was necessary for the successful expansion of their businesses outside the enclave. Opportunity readiness has a unique meaning in the context of a small business. It refers to an owner's readiness to seek and avail themselves of business opportunities. The theme opportunity readiness is composed of several components. Some of these components are the degree of articulation of one's business model, the entrepreneurs' possession of sufficient managerial experience to recognize the need for strategic shifts, and the utilization of breakout strategies that represent an accumulation of entrepreneurial attitudes. Opportunity readiness was discussed by $100 \%$ of the interviewees, a total of 42 times across all interviews.

The emergence of this theme contrasts the two approaches to entrepreneurship espoused by Chrysostome and Lin (2010): necessity entrepreneurship versus opportunity entrepreneurship. Opportunity entrepreneurship has an intrinsic link to the availability of markets and occurs as a result of methodical strategic planning (Beckers \& Blumberg, 2013). Under this construct, immigrant entrepreneurs leverage their accumulated human capital—education, experience, family connections, and individual learning initiatives-for business creation. Several responses by study participants substantiate the tenant of this approach that explains that if there is latent demand for a product or service, then a business opportunity exists for entrepreneurs to capitalize on and to create value derived from exploiting such opportunity.

In contrast, necessity entrepreneurs are individuals who begin their enterprises because they see no better alternative or have no better alternative in the wage sector (Poschke, 2013). Circumstances force necessity entrepreneurs to undertake business ventures as they encounter obstacles that hinder them from participating in the traditional labor market. Indications of necessity entrepreneurship were not observed in any of the participants interviewed.

\section{Theme 2: Multicultural Hybridism}

The term multicultural hybridism has emerged from recent research of immigrant entrepreneurship to explain the increasing managerial competences, human capital, and level of entrepreneurial commitment necessary to sustain the exploration and exploitation of business opportunities (Arrighetti et al., 2014). In general, this finding is consistent with findings of Arrighetti et al., who 
posited that the adoption of multicultural hybridism is a key antecedent to the adoption of growth strategies outside ethnic enclave. This finding also aligns with Baycan Levent, Masurel, and Nijkamp (2003) who found that immigrant entrepreneurs crossing the boundaries of enclave markets need the capacity to attract assets and resources to their firms, such as management skills, market information, and technological knowledge.

Topics related to this theme that were also discussed by the participants were the professionalization of the firm, the development of innovative organizational configurations, and the formalization of operations. Professionalization of the firm was of particular importance to the participants. It included hiring professionals with increased managerial expertise such as skills in financial management, marketing, or logistics. The professionalization process also represented a move away from family-based labor in an attempt to increase the venture's access to professional skills or English language skills. Multicultural hybridism was discussed by $100 \%$ of the interviewees, a total of 30 times across all interviews.

\section{Theme 3: Proficiency in the Predominant Language and Culture Outside of the Enclave}

When discussing reasons that they were able to grow outside the enclave and cater to other customers, all participants emphasized the importance of proficiency in the English language. Participants discussed the ability to communicate effectively in all business aspects as a necessity for expansion outside the enclave, whereas lacking language skills were named as a barrier to business growth. Participants underscored the need to be proficient not just in the English language, but also in the predominant culture outside the enclave, so as to understand the desired customer experience of larger markets. This theme aligns with the conclusions of researchers Anastasia, Dimitrios, Anastasios, and Andreas (2014) and Shields and Price (2004), who found that immigrant entrepreneurs that were proficient in English earned better economic returns of their efforts. Wang (2011) studied the role that the ability to communicate in English plays in business formation and integration, and confirmed what other more recent studies have also concluded (Kushnirovich, Heilbrunn, \& Davidovich, 2017) that lack of proficiency is a hindrance to immigrant entrepreneurial venture formation and integration. The importance of proficiency in English language and in the predominant culture "outside the enclave" was discussed by $100 \%$ of the interviewees, a total of 11 times across all interviews.

\section{Theme 4: Access to Training, Mentorship, and Professional Networks}

Participants discussed the importance of accessing nonfinancial resources, specifically training and educational opportunities, formal and informal mentorship, and professional networks, to growing their businesses outside of the ethnic enclave. Participants provided examples of how networking and mentorship has positively impacted their ability to do business, by advancing their ability to tap into new markets. Some participants considered that intentional connectivity and participation in formal and informal peer and mentorship networks enhanced their ability to grow in social sophistication and business acumen. These ideas align with common recommendations in findings from Almobaireek and Manolova (2012), Brush and Cooper (2012), and Emrich (2015). This theme also aligns well with the findings of Kallick (2015) and Wingfield and Taylor (2016), whose research highlighted the benefits of establishing spaces that expand the opportunities to learn about American business practices. Access to training, mentorship, and professional networks was discussed by $100 \%$ of the interviewees, a total of 20 times across all interviews. 


\section{Theme 5: Connectedness to Financial Resources}

Participants discussed the significance of their level of connectedness to financial resources and the ways in which this type of connection has changed over the lifespan of their businesses. Aspects of this theme include their initial lack of access to, or trust in, financial institutions, the degree to which they relied upon loans for initial operating cash flow, and their increased ability to rely on financial institutions as the business grew. All the participants developed stronger relationships with financial institutions as their business successfully grew outside the enclave. Notwithstanding the challenges that participants had accessing financial resources when they initially launched their businesses, all participants commented that when it was time to expand their business beyond the enclave, they had developed solid relationships with financial institutions. Also, that their ability to invest in reaching markets outside the enclave has been enhanced by having those solid relationships with financial institutions. The findings indicate that lack of connectivity to financial tools primarily occurred during the startup phase of the businesses. However, once their business was established, access to banking services became more readily available. Connectedness to financial resources was discussed by $100 \%$ of the interviewees, a total of 14 times across all interviews.

\section{Theme 6: Tenacity and Resilience in the Business}

Participants in this study frequently expressed that personal tenacity and resilience to hardship and obstacles were important to achieve the successful expansion of their businesses outside of the ethnic enclave. This finding aligns with the finding of Allen and Busse (2015), Pisani et al. (2012), Price (2012), and Wilson and Portes (1980). Additionally, Fisher, Maritz, and Lobo (2014) concluded that entrepreneurs of any background, race, or ethnicity are more resilient than nonentrepreneurs, and that personal resilience does predict entrepreneurial success. Tenacity and resilience in the business was discussed by $100 \%$ of the interviewees, a total of 14 times across all interviews.

\section{Possible Strategies for Immigrant Business Owners to Expand Outside of Their Enclave}

\section{Strategy 1: Multicultural Hybridism}

Immigrant business owners desiring to expand beyond their ethnic enclave should consider revising their business model, specifically their products and services, to a more multicultural model. Having a more ethnically diverse group pf employees and supervisors can help business be more successful outside an ethnic enclave. A reliance on a multicultural model within the firm seems to leverage the benefits of human diversity and to increase the success of such firms in meeting customers' expectations, and promoting not only integration within the business domain, but within the broader economic ecosystem in which they operate.

\section{Strategy 2: Language and Cultural Proficiency}

It's clear from the experiences shared by the study participants that their language skills have been an important tool for integration into the host community. Immigrant entrepreneurs should take steps to become proficient in the primary language of their host community. While it appears from the study that $100 \%$ proficiency is not necessary, immigrant entrepreneurs who are able to conduct business, negotiate terms, and provide customer support in English tend to be more successful in expanding beyond their enclave.

\section{Strategy 3: Seek and Nurture Professional Development and Mentorship Opportunities}

Immigrant entrepreneurs wanting to grow their business outside their enclave seek, find, and nurture professional development and mentorship relationships. Mentors act as sounding boards in 
evaluating ideas and providing feedback on major business decisions. They often offer helpful perspectives as they share their knowledge and experience. Participants emphasized the importance of learning from other successful entrepreneurs and business owners, both from their successes and from their mistakes. Having the opportunity to learn from peers and mentors can help with making the right decisions and with avoiding pitfalls. Membership in ethnic and non-ethnic groups such as professional organizations, business groups, trade groups, chambers of commerce, and cultural and recreational entities can be beneficial to the entrepreneur. Table 1 summarizes specific recommended strategies and implementation actions for immigrant entrepreneurs wishing to expand their businesses outside their enclave.

Table 1. Recommended Strategies and Implementation Actions

\begin{tabular}{|c|c|}
\hline Recommended Strategies & Recommended Implementation Actions \\
\hline $\begin{array}{l}\text { Adopt a multicultural and flexible } \\
\text { business model that allows the } \\
\text { business to be ready to assess } \\
\text { and capitalize on expansion } \\
\text { opportunities }\end{array}$ & $\begin{array}{l}\text { Craft a flexible business model so the business can react to } \\
\text { market opportunities } \\
\text { Foster entrepreneurial commitment and thinking within the } \\
\text { business }\end{array}$ \\
\hline $\begin{array}{l}\text { Strengthen proficiency in the } \\
\text { English language and in the } \\
\text { predominant culture outside the } \\
\text { enclave }\end{array}$ & $\begin{array}{l}\text { Increase managerial competence by focusing on talent } \\
\text { development } \\
\text { Implement strategies that allow for the professionalization of } \\
\text { the venture } \\
\text { Work toward acculturation in host community's business and } \\
\text { economic practices } \\
\text { Acquire proficiency in the English language and in the } \\
\text { predominant culture outside the enclave }\end{array}$ \\
\hline $\begin{array}{l}\text { Seek, find, and nurture } \\
\text { professional development and } \\
\text { mentorship relationships }\end{array}$ & $\begin{array}{l}\text { Participate in professional membership groups, such as } \\
\text { chambers of commerce or professional networks } \\
\text { Get involved in mentorship programs } \\
\text { Intentionally seek help from other professionals } \\
\text { Join entrepreneurs' organizations } \\
\text { Acquire relevant certifications } \\
\text { Develop a relationship with a banker early on, even if } \\
\text { financing is not yet necessary } \\
\text { Understand the financing and investment landscape within } \\
\text { the entrepreneurial ecosystem }\end{array}$ \\
\hline
\end{tabular}

\section{Discussion and Conclusions}

\section{Limitations}

Because this research was specific to the Latino ethnic group in the Nashville geographic region, the findings may not be representative of other defined groups in other locations. We acknowledge that the limited number of study participants means that the findings cannot be considered conclusive. However, a qualitative exploration such as this research adds to the body of knowledge and can assist in the conceptualization of models and theories that can be tested using a different research method and design. We acknowledge that despite reasonable precautions, a purposeful, nonrandom sample could include some unintentional and unrecognized selection bias. 


\section{Applications to Professional Practice}

Entering mainstream markets means immigrant-owned businesses integrating within the broader business economic, organizational, and cultural capabilities of the host community. The findings of the study provided some relevant strategies that immigrant business owners have followed to grow their businesses beyond their ethnic enclave. The findings suggest that growing outside the enclave is indeed a strategy that can be used to impact the success and profitability of the entrepreneur.

The findings indicate that adopting multicultural hybridism as a business strategy offers firms a path towards successful growth outside their enclave. Within the context of multicultural hybridism, the research findings indicate that Latino immigrant-owned businesses should be as proficient as possible in the English language to be able to reach a broader customer base. Their language skills do not need to be perfect, but they have to feel confident in their abilities to communicate with nonSpanish speakers to be able to lead, negotiate, and serve different venture stakeholders.

Additionally, the findings point to the importance of immigrant entrepreneurs being connected to a broader network of stakeholders that offers mentorships or peer interactions.

Finally, the results do not seem to support the notion that for the immigrant entrepreneur, a lack of relationships with financial institutions and financial services in general is a detriment to growing their businesses during the startup phase. This finding is at odds with the literature and common perception that banks and other financial institutions do not serve the needs of immigrant-owned businesses on a growth pattern (Bates \& Robb, 2013; Carter, Mwaura, Ram, Trehan, \& Jones, 2015). The participants in this research resorted to personal savings, as well as friends and family when they started their businesses, and did not use banks until the businesses had already been established. However, once their businesses were established and successful, the owners developed solid relationships with banks and other financial institutions. If put to action, some or all of the recommended strategies may help immigrant business owners reach higher levels of success as they attempt to expand their businesses outside for their ethnic enclave.

\section{Implications for Social Change}

Immigrant entrepreneurs make a direct contribution to the economy of the communities in which they operate and are increasingly seen as key players in enhancing the prosperity of the broader community. Immigrant entrepreneurs and business owners who use the recommended strategies to expand their businesses beyond the enclave can become better corporate citizens, provide a broader tax contribution and employ more people, and play a positive role in economic development within the communities in which they operate. To the extent that immigrant owned businesses are able to successfully grow their businesses outside their enclave, the outcomes can have positive ramifications for these immigrant entrepreneurs, their families, and society at large.

\section{Recommendations for Further Research}

We recommend that the themes and possible strategies identified from this research are potentially significant enough to warrant further research to ascertain their applicability to other defined groups and geographic locations. Additional qualitative research could use a much larger sample and multiple geographically and social diverse locations. Based on the findings of this research, perhaps a qualitative research model could be developed and tested using a large-scale quantitative or mixedmethod survey and a statistically valid sample of defined populations.

Researchers could also explore the relevance of other institutional factors, such as particular industry, gender roles, or immigration status, and their impact on success strategies that help 
business owners grow outside their enclave. Given the participants' perceived importance of mentoring and access to professional networks, in-depth research that explores the impact of intentional and active participation in such activities on the success of businesses could be significant.

\section{References}

Agius, J., \& Canizales, S. L. (2016). Latino/a professionals as entrepreneurs: How race, class, and gender shape entrepreneurial incorporation. Ethnic and Racial Studies, 39, 1637-1656. doi:10.1080/01419870.2015.1126329

Allen, R., \& Busse, E. (2015). The social side of ethnic entrepreneur breakout: Evidence from Latino immigrant business owners. Ethnic and Racial Studies, 39, 653-670. doi:10.1080/01419870.2015.1078481

Almobaireek, W. N., \& Manolova, T. S. (2012). Who wants to be an entrepreneur? Entrepreneurial intentions among Saudi university students. African Journal of Business Management, 6 , 4029-4040. doi:10.5897/AJBM11.1521

Anastasia, B., Dimitrios, P., Anastasios, K., \& Andreas, A. (2014). Factors influencing the successful entrepreneurship of immigrants: The case of kavala and drama city. European Journal of Business and Social Sciences, 2, 139-154. Retrieved from http://www.ejbss.com/Data/Sites/1/vol2no11feb2014/ejbss-1346-14factorsinfluencingthesuccessfulentrepreneurship.pdf

Arrighetti, A., Bolzani, D., \& Lasagni, A. (2014). Beyond the enclave? Break-outs into mainstream markets and multicultural hybridism in ethnic firms. Entrepreneurship and Regional Development, 26, 753-777. doi:10.1080/08985626.2014.992374

Bates, T., \& Robb, A. (2013). Greater access to capital is needed to unleash the local economic development potential of minority-owned businesses. Economic Development Quarterly, 27, 250-259. doi:10.1177/0891242413477188

Baycan Levent, T., Masurel, E., \& Nijkamp, P. (2003). Diversity in entrepreneurship: Ethnic and female roles in urban economic life. International Journal of Social Economics, 30, 11311161. doi:10.1108/03068290310497495

Braymen, C., \& Neymotin, F. (2014). Enclaves and entrepreneurial success. Journal of Entrepreneurship and Public Policy, 3, 197-221. doi:10.1108/jepp-08-2012-0039

Beckers, P., \& Blumberg, B. F. (2013). Immigrant entrepreneurship on the move: A longitudinal analysis of first- and second-generation immigrant entrepreneurship in the Netherlands. Entrepreneurship and Regional Development, 25, 654-691. doi:10.1080/08985626.2013.808270

Brush, C. G., \& Cooper, S. Y. (2012). Female entrepreneurship and economic development: An international perspective. Entrepreneurship \& Regional Development, 24, 1-6. doi:10.1080/08985626.2012.637340

Buzdugan, R., \& Halli, S. S. (2009). Labor market experiences of Canadian immigrants with focus on foreign education and experience. International Migration Review, 43, 366-386. doi:10.1111/j.1747-7379.2009.00768.x 
Carter, S. (2011). The rewards of entrepreneurship: exploring the incomes, wealth, and economic well-being of entrepreneurial households. Entrepreneurship: Theory and Practice, 35, 39-55. doi:10.1111/j.1540-6520.2010.00422.x

Carter, S., Mwaura, S., Ram, M., Trehan, K., \& Jones, T. (2015). Barriers to ethnic minority and women's enterprise: Existing evidence, policy tensions and unsettled questions. International Small Business Journal, 33, 49-69. doi:10.1177/0266242614556823

Chand, M., \& Ghorbani, M. (2011). National culture, networks and ethnic entrepreneurship: A comparison of the Indian and Chinese immigrants in the U.S. International Business Review, 20, 593-606. doi:10.1016/j.ibusrev.2011.02.009

Chrysostome, E., \& Lin, X. (2010). Immigrant entrepreneurship: Scrutinizing a promising type of business venture. Thunderbird International Business Review, 52, 77. doi:10.1002/tie.20315

Creese, G., \& Wiebe, B. (2012). Survival employment: Gender and deskilling among African immigrants in Canada. International migration, 50(5), 56-76. doi:10.1111/j.14682435.2009.00531.x

Curci, R., \& Mackoy, R. (2010). Immigrant business enterprises: A classification framework conceptualization and test. Thunderbird International Business Review, 52, 107. doi:10.1002/tie.20318

Emrich, K. (2015). Profitability and the financial strategies of women-owned small businesses (Doctoral dissertation). Retrieved from ProQuest Dissertations and Theses database. (UMI 3680364)

Ensign, P. C., \& Robinson, N. P. (2011). Entrepreneurs because they are immigrants or immigrants because they are entrepreneurs? A critical examination of the relationship between the newcomers and the establishment. Journal of Entrepreneurship, 20, 33-53. doi:10.1177/097135571002000102

Fisher, R., Maritz, A., \& Lobo, A. (2014). Resilience in entrepreneurs. Academy of Management Proceedings, 2014, 11260-11260. doi:10.5465/ambpp.2014.11260abstract

Fitzgerald, C., \& Howe-Walsh, L. (2009). Self-initiated expatriates: An interpretative phenomenological analysis of professional female expatriates. International Journal of Business and Management, 3, 156-175. doi:10.5539/ijbm.v3n10p156

Huerta, A. (2011). Examining the perils and promises of an informal niche in a global city: A case study of Mexican immigrant gardeners in Los Angeles (Doctoral dissertation). Retrieved from ProQuest Dissertations and Theses database. (UMI 3498982)

Ibrahim, G., \& Galt, V. (2011). Explaining ethnic entrepreneurship: An evolutionary economics approach. International Business Review, 20, 607-613. doi:10.1016/j.ibusrev.2011.02.010

Ilhan-Nas, T., Sahin, K., \& Cilingir, Z. (2011). International ethnic entrepreneurship: antecedents, outcomes and environmental context. International Business Review, 20, 614-626.

doi:10.1016/j.ibusrev.2011.02.011

Jennings, P. D., Greenwood, R., Lounsbury, M. D., \& Suddaby, R. (2013). Institutions, entrepreneurs, and communities: A special issue on entrepreneurship. Journal of Business Venturing, 28, 1-9. doi:10.1016/j.jbusvent.2012.07.001

Kallick, D. (2015). Bringing vitality to Main Street: How immigrant small businesses help local economies grow. Retrieved from http://www.as-coa.org/articles/bringing-vitality-main-streethow-immigrant-small-businesses-help-local-economies-grow 
Kim, A. J. (2012). Labor market migrations: Immigrant intersections in the informal economy. AAPI Nexus: Policy, Practice and Community, 10, 75-99. doi:10.17953/appc.10.1.73j36h8383545t53

Kirkwood, J. (2009). Motivational factors in a push-pull theory of entrepreneurship. Gender in Management: An International Journal, 24, 346-364. doi:10.1108/17542410910968805

Krittayapong, J. (2012). Robin Hood in the land of the free? An ethnographic study of undocumented immigrants from Thailand in the U.S. (Doctoral dissertation). Ohio University, Athens, Ohio.

Kushnirovich, N., Heilbrunn, S., \& Davidovich, L. (2017). Diversity of entrepreneurial perceptions: Immigrants vs. native population. European Management Review. Advance online publication. doi:10.1111/emre.12105

Kwon, S.-W., Heflin, C., \& Ruef, M. (2013). Community social capital and entrepreneurship. American Sociological Review, 78, 980-1008. doi:10.1177/0003122413506440

Lofstrom, M. (2011). Does self-employment increase the economic well-being of low-skilled workers? Small Business Economics, 40, 933-952. doi:10.1007/s11187-011-9402-z

Ma, Z., Zhao, S., Wang, T., \& Lee, Y. (2013). An overview of contemporary ethnic entrepreneurship studies: Themes and relationships. International Journal of Entrepreneurial Behaviour \& Research, 19, 32-52. doi:10.1108/13552551311299242

Miles, M. B., Huberman, A. M., \& Saldana, J. (2014). Qualitative data analysis: Method source book. Los Angeles, CA: Sage.

Ndofor, A. H., \& Priem, R. L. (2011). Immigrant entrepreneurs, the ethnic enclave strategy, and venture performance. Journal of Management, 37, 790-818. doi:10.1177/0149206309345020

Ortiz-Walters, R., Gavino, M. C., \& Williams, D. (2015). Social networks of Latino and Latina entrepreneurs and their impact on venture performance. Academy of Entrepreneurship Journal, 21, 58-81. Retrieved from http://www.alliedacademies.org/academy-ofentrepreneurship-journal/

Pandya, C., Batalova, J., \& McHugh, M. (2011). Limited English proficient individuals in the United States: Number, share, growth, and linguistic diversity. Washington, DC: Migration Policy Institute. Retrieved from https://eric.ed.gov/?id=ED527752

Pisani, M. (2012) Latino informal immigrant entrepreneurs in South Texas: Opportunities and challenges for unauthorized new venture creation and persistence. American Journal of Business, 27, 27-39 doi:10.1108/19355181211217625

Poschke, M. (2013). Entrepreneurs out of necessity: A snapshot. Applied Economics Letters, 20, 658663. doi:10.1080/13504851.2012.727968

Price, M. D. (2012), Hispanic entrepreneurship in a global city: The Bolivian diaspora in Washington, DC. In E. S. Pumar (Ed.), Hispanic migration and urban development: Studies from Washington DC: Research in race and ethnic relations (Vol. 17, pp.133-153). Bingley, United Kingdom: Emerald Group. doi:10.1108/S0195-7449(2012)0000017009

Raijman, R., \& Kemp, A. (2009). Israel: The new immigration to Israel: Becoming a de facto immigration state in the 1990s. In U. A. Segal, D. Elliott, \& N. S. Mayadas (Eds.), Immigration worldwide: Policies, practices, and trends (pp. 227-243). New York, NY: Oxford University Press. doi:10.1093/acprof:oso/9780195388138.003.0015

Riva, E., \& Lucchini, M. (2015). The effect of the country of birth of the owner on business survival: Evidence from Milan metropolitan area, Italy. Journal of Ethnic and Migration Studies, 41, 1794-1814. doi:10.1080/1369183X.2015.1015971 
Salcido, O., \& Menjívar, C. (2012). Gendered paths to legal citizenship: The case of Latin-American immigrants in Phoenix, Arizona. Law \& Society Review, 46, 335-368. doi:10.1111/j.15405893.2012.00491.x

Shields, M. A., \& Wheatley Price, S. (2004). The English language fluency and occupational success of ethnic minority immigrant men living in English metropolitan areas. In K. F.

Zimmermann \& A. Constant (Eds.), How labor migrants fare: Population economics (pp. 167190). Berlin, Germany: Springer. doi:10.1007/978-3-540-24753-1_9

Simmel, G. (1950). The sociology of Georg Simmel. New York, NY: The Free Press.

Sombart, W. (1914). The Jews and modern capitalism. New Brunswick, NJ: Transaction.

Teece, D. J. (2012). Dynamic capabilities routines versus entrepreneurial action. Journal of Management Studies, 49, 1395-1401. doi:10.1111/j. 467-6486.2012.01080.x

Teece, D. J., Pisano, G., \& Shuen, A. (1997). Dynamic capabilities and strategic management. Strategic Management Journal, 18, 509-533. doi:10.1002/(SICI)10970266(199708)18:7<509::AID-SMJ882>3.0.CO;2-Z

Trevizo, D., \& Lopez, M. J. (2016). Neighborhood segregation and business outcomes: Mexican immigrant entrepreneurs in Los Angeles County. Sociological Perspectives, 59, 668-693. doi:10.1177/0731121416629992

Wang, Q. (2011). African American and Hispanic self-employment in the Charlotte metropolitan area. Southeastern Geographer, 51, 89-109. doi:10.1353/sgo.2011.0007

Weber, M. (1930). The Protestant ethic and the spirit of capitalism. New York, NY: Scribner.

Wilson, K. L., \& Portes, A. (1980). Immigrant enclaves: An analysis of the labor market experiences of Cubans in Miami. American Journal of Sociology, 86, 295-319. doi:10.1086/227240

Wingfield, A. H., \& Taylor, T. (2016). Race, gender, and class in entrepreneurship: Intersectional counterframes and black business owners. Ethnic and Racial Studies, 39, 1676-1696. doi:10.1080/01419870.2016.1178789

Xie, Y., \& Gough, M. (2011). Ethnic enclaves and the earnings of immigrants. Demography, 48, 1293-1315. doi:10.1007/s13524-011-0058-8

Zolin, R., \& Schlosser, F. (2012). Characteristics of immigrant entrepreneurs and their involvement in international new ventures. Thunderbird International Business Review, 55, 271-284. doi:10.1002/tie.21543

The International Journal of Applied Management and Technology (IJAMT), sponsored by Walden University's School of Management, is a peer-reviewed, online journal that addresses contemporary national and international issues related to management and technology. The objectives of the IJAMT are to: (a) encourage collaborative and multi-disciplinary examinations of important issues in business and technology management, and (B) engage scholars and scholar-practitioners in a dynamic and important dialogue.

Walden University Publishing: http://www.publishing.waldenu.edu 